\title{
KRITIK INTRINSIKALITAS DAN EKSTRINSIKALITAS SASTRA MODERN \\ DALAM KAJIAN SASTRA ARAB MODERN
}

\author{
Abd Aziz \\ STIT Al-Amin Kreo Tangerang \\ azizindunisi@gmail.com \\ M. Imam Sofwan Yahya \\ Kepala Pondok Pesantren Luhur Al-Tsaqafah \\ sofwanism@gmail.com
}

\begin{abstract}
In the practice of literary criticism, including Arabic literature, there are two approaches in evaluating literary works, namely the intrinsic approach and the extrinsic approach. The intrinsic approach bases itself on the objective value of literary works itself without connecting with other sciences, or approaches that seek to see literary works objectively with the propositions of linguistics and literary aesthetics. From this approach was born a flow of semiotic literary criticism and structural literary criticism. Meanwhile, the extrinsic approach uses certain scientific measures in evaluating literary works. The extrinsic approach to literary criticism seeks to see literary works from the viewpoint of disciplines outside of literature. This approach gave birth to sociological literary criticism, psychological literary criticism, archaeological literary criticism, moral literary criticism, philosophical literary criticism, and others.
\end{abstract}

Keywords: criticism, intrinsic, extrinsic, modern Arabic literature

\begin{abstract}
ABSTRAK
Dalam praktik kritik sastra, termasuk di dalamnya sastra Arab, terdapat dua pendekatan dalam menilai karya sastra, yaitu pendekatan intrinsik dan pendekatan ekstrinsik. Pendekatan intrinsik mendasarkan diri pada nilai objektif karya sastra itu sendiri tanpa menghubung-hubungkan dengan ilmu lain, atau pendekatan yang berusaha melihat karya sastra secara objektif dengan dalil ilmu bahasa dan estetika sastra. Dari pendekatan ini lahir aliran kritik sastra semiotik dan kritik sastra struktural. Sementara itu, pendekatan ekstrinsik menggunakan ukuran ilmu tertentu dalam menilai karya sastra. Pendekatan ekstrinsik dalam kritik sastra berusaha melihat karya sastra dari sudut pandang disiplin ilmu di luar sastra. Pendekatan ini melahirkan kritik sastra sosiologis, kritik sastra psikologis, kritik sastra arketip, kritik sastra moral, kritik sastra filsafat, dan lainnya.
\end{abstract}

Kata Kunci: kritik, intrinsik, ekstrinsik, sastra Arab modern 


\section{A. PENDAhuluan}

Kata 'kritik' berasal dari bahasa Yunani, yaitu dari kata krino, yang berarti mengelurkan hukum, krites yang berarti hakim atau orang yang menghakimi, juga kritikos - yang muncul pada abad 4 SM - yang berarti orang yang mengelurakan sebuah hukum mengenai sastra. ${ }^{1}$ Berarti, berdasarkan arti etimologi tersebut, kata kritik biasanya dipahami sebagai proses meneliti, menghakimi, membandingkan, atau menimbang sesuatu dan membedakan karakternya antara yang baik dan yang buruk, dan menilainya sesuai dengan kriteria atau batasan tertentu. ${ }^{2}$

Kritik atau dalam bahasa Arab disebut naqd al-adab secara umum berarti membicarakan sesutau, dari sudut manapun, dengan cara apapun, dan siapa pun subjeknya. Secara etimologi, naqd berarti noda, cela, atau buruk. ${ }^{3}$ Hal ini sejalan dengan definisi materi nun-qaf-dal dalam Lisa>n al-'Arab yang berarti memilah atau memisah dirham dengan tujuan untuk membedakan antara yang bagus dan buruknya. Dengan ini, maka naqd berarti memaparkan sesuatu untuk menilai aspek baik dan bagian buruknya. Terkadang juga kritik dimaknai lebih sempit lagi sebagai penelitian yang memusatkan pada bagian negatif sesuatu. Ini berarti naqd berlawanan dengan istilah taqrizh, yang berarti memuji manusia, karya, atau apa pun. ${ }^{4}$

Dalam arti luas, atau secara terminologis, kritik mengandung semangat aktivitas mengapresiasi dengan cara deskripsi, analisis, interpretasi, ataupun penilaian karya sastra. Definisi ini memberikan makna lebih terhadap istilah kritik sastra sebagai sebuah upaya dan proses dialog, perdebatan, atau pertukaran pandangan dan pikiran di antara beberapa subjek. ${ }^{5}$ Kesimpulannya, kata kritik menyimpan makna apresiasi secara proposional terhadap suatu objek dengan cara memujinya dan menjelekkannya. ${ }^{6}$ Menurut Ihsan Abbas, kritik adalah ungkapan sikap dalam melihat seni, khususnya puisi, melalui intuisi rasa dengan cara menafsirkan, menganalisis, dan menilai yang saling berkelindan. ${ }^{7}$

Kemudian, yang dimaksud dengan sastra atau $a d a b$ dalam lingkup kritik di sini adalah seni estetik yang mengandung unsur rasa, imajinasi, makna, dan gaya bahasa. ${ }^{8}$ Jadi, karya kreatif dan imajinatif, dalam pembahasan ini adalah karya tulis yang berbentuk prosa (cerpen, novel, dan roman), puisi, dan drama. Bukan yang terkait dengan makna hidangan, makanan, sopan santun, tata krama, etika atau akhlak, meskipun secara bahasa, kata adab mengandung makna-makna tersebut. ${ }^{9}$ Definisi $a d a b$ ini juga menegasikan karya-karya tulis umum yang pada awal perkembangan mencakup segala karya tulisan yang dihasilkan dari pemikiran manusia.

Oleh karena itu, kritik sastra adalah ilmu sastra yang berusaha menyelidiki karya sastra dengan menganalisis, memberi pertimbangan baik buruknya karya sastra, bernilai seni atau tidaknya. ${ }^{10}$ Kritik sastra juga dipahami sebagai bagian dari ilmu sastra yang

1 Batul Qasim Nashir, Muhadharat fi al-Naqd al-Arabi, (Baghdad: Markaz al-Syahidain alShadrain, 2008), hlm. 11 2012), hal. 51

${ }^{2}$ Sukron Kamil, Teori Kritik Sastra Arab Klasik dan Modern, (Jakarta: RajaGrapindo Persada,

${ }^{3}$ Ahmad Amin, al-Naqd al-Adabi, (Kairo: Kalimat Arabia, 2012), hlm. 13.

${ }^{4}$ Ahmad Amin, al-Naqd al-Adabi, hlm. 13.

${ }^{5}$ Batul Qasim Nashir, Muhadharat fi al-Naqd al-Arabi, hlm. 4.

${ }^{6}$ Sukron Kamil, Teori Kritik Sastra Arab Klasik dan Modern, hal. 51

${ }^{7}$ Ihsan Abbas, Tarikh al-Naqd al-Adab 'Inda al- 'Arab, (Beirut: Daar Al-Tsaqafah, 1983), cet. 3, hlm. 5 .

${ }^{8}$ Ahmad Amin, al-Naqd al-Adabi, hlm. 30-60

${ }^{9}$ Sukron Kamil, Teori Kritik Sastra Arab Klasik dan Modern, hal. 3-5

${ }^{10}$ Rachmat Djoko Pradopo, Prinsip-Prinsip Karya Sastra, (Yogyakarta: Gadjah Mada University Press, 2007), hlm. 9. 
mempelajari karya sastra dengan memberikan pertimbangan dan penilaian atas baikburuknya, kekuatan, dan kelemahan karya sastra. ${ }^{11}$ Kritik sastra termasuk dalam sastra deskriptif yang membincangkan pemahaman, penghayatan, penafsiran, dan penilaian terhadap karya sastra. ${ }^{12}$

Dengan demikian, definisi kritik sastra mengilhami fungsi kritik sastra itu sendiri. Sebagaimana dianut beberapa kritikus sastra dalam memberikan pendapatnya mengenai definisi sastra yang menurutnya berfungsi untuk interpretasi, penilaian, dan kontrol terhadap sastra. Penafsiran sastra lebih mengedepankan penjelasan sastra dari sisi sumber, tujuan, dan karakteristiknya. Penilaian sastra berpijak dari dalam karya sastra itu sendiri, bukan bersumber dari ukuran, teori, dan kaidah di luar sastra. Sementara itu, fungsi kontrol sastra merupakan upaya mengarahkan sastra atau sastrawan agar tetap berada dalam koridor nilai-nilai kemanusiaan dan estetika dalam karya-karyanya. Fungsi kritik sastra yang terakhir adalah sebagai mediator antara sastra dan norma atau nilai kebudayaan. Ini didasarkan pada alasan bahwa sastra tidak terlepas dari nilai budaya tertentu. Sebab itu, kritik sastra tidak dapat melepaskan diri dari kaidah atau metode ilmu-ilmu lain karena kelimuan non-sastra berkelindan dengan budaya yang memengaruhi karya sastra tertentu. ${ }^{13}$

Menurut Sukron Kamil, kritik sastra setidaknya memiliki tiga fungsi. Pertama, menjelaskan karya sastra. Hal ini dikarenakan bahasa yang digunakan karya sastra terutama puisi - seringkali berbeda dengan bahasa kebiasaan sehari-hari. Bahasa sastra bersifat padat, metaforis, dan simbolik yang menyebabkam makna yang terkandung di dalamnya bukan yang tersurat tetapi yang tersirat. Kedua, meluruskan kekeliruan karya sastra dari kaidah-kaidah bahasa, logika, moral, teori sastra, dan kekeliruan estetikanya. Dalam fungsi pelurusan ini, kritik sastra juga berfungsi membantu sastrawan pemula dalam meningkatkan karya sastranya sehingga menjadi sastrawan besar. Ketiga, menunjang ilmu sastra. Analisis sastra dari para kritikus memberi sumbangan besar dalam pengembangan teori dan sejarah sastra, karena saling berhubungan. ${ }^{14}$

Selain tiga fungsi di atas, kritik sastra juga memiliki peran penting dalam pembinaan tradisi kultural. Maksudnya, kritik sastra memberi pertimbangan dan pandangan dalam membaca sastra dengan takaran cita rasa yang benar, sehingga kritik sastra dapat menjadi pemicu tumbuhnya kesadaran kultural terhadap makna dan nilai kehidupan melalui karya-karya sastra. ${ }^{15}$ Oleh sebab itu, demi menunjang kritik sastra yang baik, maka setidaknya harus memenuhi beberapa unsur penting, yaitu: (1) objektivitas dan kejujuran serta menjauhkan diri dari prasangka, (2) memahami konteks lingkungan budaya dan tata nilai yang berlaku, (3) memberi pengaruh terhadap pembaca dalam berpikir kritis sehingga dapat meningkatkan apresiasi masyarakat terhadap sastra, dan (4) mampu memperbaiki cara berpikir dan cara bekerja para sastrawan. ${ }^{16}$

\section{B. PEMBAHASAN}

\section{Sejarah Kritik Sastra Arab ${ }^{17}$}

${ }^{11}$ Suhariyadi, Pengantar Ilmu Sastra; Orientasi Penelitian Sastra, (Lamongan: Pustaka Ilalang, 2014), hlm. 17.

${ }^{12}$ Sukron Kamil, Teori Kritik Sastra Arab Klasik dan Modern, hal. 5.

${ }^{13}$ Batul Qasim Nashir, Muhadharat fi al-Naqd al-Arabi, hlm. 6-9.

${ }^{14}$ Sukron Kamil, Teori Kritik Sastra Arab Klasik dan Modern, hal. 53.

15 Suminto A. Sayuti, "Kritik Sastra: Sebuah Tinjauan Umum”, Jurnal Diksi, No. 1 Tahun 1, Januari 1993.

16 Suminto A. Sayuti, "Kritik Sastra: Sebuah Tinjauan Umum”, Jurnal Diksi, No. 1 Tahun 1, Januari 1993.

${ }^{17}$ Sukron Kamil, Teori Kritik Sastra Arab Klasik dan Modern, hal. 56-59. 
Dalam kritik sastra Arab saat ini, setelah melewati masa yang panjang dari klasik hingga modern, dari yang orisinal Arab hingga pertemuannya dengan tradisi sastra Helenik dan tradisi sastra Barat modern- sebagaimana diungkap Muhammad Hasan Abdullah, terdapat banyak metode kritik sastra. Kritik sastra telah muncul sejak masa pra-Islam (jahiliyah) yang berkisar pada kritik kebahasaan. Pada masa awal Islam, kritik berkembang kepada penilaian baik-buruk kandungan atau substansi makna puisi. Pada abad ketiga hijriyah, kritik sastra arab memulai terstruktur dan tersistem dengan munculnya para kritikus yang menghasilkan kaidah dan teori kebahasaan seperti Ibn Qutaibah dan al-Jahizh. Perkembangan kritik sastra mematang pada abad empat dan lima hijriyah metode badi', perbandingan, bayan, dan aspek kebahasan dan balaghah lainnya.

Pada abad keenam hijriyah, kritik sastra menghadapi kemandegan karena penjajahan Barat, meskipun muncul ada beberapa kritikus yang pada abad ini seperti Ibnu al-Atsir dan Ibnu Sina al-Malik. Pada abad modern 13-14 hijriyah muncul beberapa mazhab kritik sastra, yaitu (1) kritik sastra klasik, yang berpijak pada kritik sastra Arab murni yang dipengaruhi al-Quran, (2) kritik sastra Barat, yang bermazhab kepada konsep dan teori sastra Barat seperti realisme, marxisme, eksistensialisme, strukturalisme, (3) kritik sastra yang menggabungkan dua aliran di atas, dan (4) kritik sastra islamis fundamentalis yang menolak tradisi kritik sastra Barat.

Dalam kesusastraan Arab, terdapat beberapa metode kritik sastra. Pertama, metode kritik linguistik, yang matang di tangan Abdul Qahir al-Jurjani yang tidak saja mementingkan interaksi dengan kata, tetapi juga struktur kalimat. Menurut para ahli metode ini, unsur-unsur linguistik yang ada dalam sastra merupakan media pertama yang membawa seorang kritikus mampu menganalisis sastra dengan baik. Kedua, metode klasik yang mementingkan pengkajian terhadap bagian-bagian kata dan makna, wazan atau bahr dalam syair, dan penguasaan khazanah sastra Arab. Ketiga, metode estetik yang mementingkan bentuk sastra, karena kekuatan dan tujuan penciptaan syair adalah keindahan bentuknya. Keempat, metode psikoanalisis yang berpijak dari ilmu psikologis untuk membongkar aspek psikologis pengarang atau karya sastranya. Kelima, aliran yang berpijak kepada mazhab sastra yang dianut oleh si pengarangnya.

\section{Kritik Intrinsik dan Ekstrinsik Sastra Arab Modern}

Dalam praktik kritik sastra, ada dua pendekatan dalam menilai karya sastra, yakni pendekatan intrinsik dan pendekatan ekstrinsik. Pendekatan intrinsik adalah pendekatan yang mendasarkan diri pada nilai objektif karya sastra itu sendiri tanpa menghubunghubungkan dengan ilmu lain. Pendekatan intrinsik berusaha melihat karya sastra secara objektif dengan dalil ilmu bahasa dan estetika sastra. Dari pendekatan ini lahir aliran kritik sastra semiotik dan kritik sastra struktural.

Sementara itu, pendekatan ekstrinsik menggunakan ukuran ilmu tertentu dalam menilai karya sastra. Pendekatan ekstrinsik dalam kritik sastra berusaha melihat karya sastra dari sudut pandang disiplin ilmu di luar sastra. Pendekatan ini melahirkan kritik sastra sosiologis, kritik sastra psikologis, kritik sastra arketip, kritik sastra moral, kritik sastra filsafat, dan lainya.

Ada juga yang disebut pendekatan campuran, yang dalam pendekatan ini kritik berusaha melihat karya sastra dari segi intrinsik maupun ekstrinsiknya. Termasuk dalam kritik sastra ini adalah kritik sastra mimetik (hubungan karya sastra dengan realitas atau kenyataan), kritik sastra ekspresif (karya sastra sebagai ekspresi, perasaan, atau imajinasi pengarang), dan kritik sastra pragmatik (kesan pembaca terhadap karya sastra). ${ }^{18}$

${ }^{18}$ Rachmat Djoko Pradopo, Prinsip-Prinsip Karya Sastra, hlm. 26. 
Pendekatan ekstrinsik sering juga disebut dengan teori interdisipliner atau sastra banding. Teori interdisipliner dipahami sebagai kajian sastra yang menghubungkannya dengan disiplin ilmu-ilmu lain, seperti filsafat, sejarah, ilmu-ilmu sosial, agama, dan lainlain. ${ }^{19}$ Teori interdisipliner ini tidak mengharuskan adanya hubungan keterpengaruhan antara dua hal yang dibandingkan. Salah satu kelebihan dari teori ini adalah mendekatkan studi sastra dengan lingkup ilmu-ilmu humaniora yang bersifat praktis.

Dari pendekatan ini lahir beberapa corak dan teori kritik sastra yang terilhami oleh displin-displin ilmu lain, diantaranya sebagai berikut:

\section{a. Teori Aliran Sastra}

Sastra secara keseluruhan, dan sastra Arab khususnya tumbuh kembang melalui fase-fase yang berbeda, seperti pertumbuhan dan perkembangan hidup manusia. Setiap jenjang atau fase memiliki karakteristik dan ciri khas masing-masing yang membedakan dengan lainnya. Fase perkembangan ini saling memengaruhi satu sama lain sampai pada perkembangan mutakhir kesusastraan pada umumnya. Aliran atau corak pertama dari perkembangan sastra Arab adalah aliran klasik ${ }^{20}$ (mazhab qadim atau madrasah kalsikiyah) yang mengagungkan dan mempertahankan konsep orsinalitas dan pokokpokok struktur sastra Arab klasik, khususnya dalam puisi. Aliran klasik lebih mengutamakan bentuk dan irama nada puisi yang berwazan yang dibangun oleh para penyair masa praislam, awal Islam, Umayyah, Abbasiyah seperti Zuhair bin Abi Sulma, Al-Hutai ah, Farazdaq, Mutanabbi, Al-Maarri, Basyyar bi Burd, Abu Nuwas, Abu Tamam, dan para penyair lainnya.

Gaya puisi klasik ini dapat dilihat dengan memerhatikan nada dan irama yang telah dikonsepkan oleh ilmu Arud. Di antara pionir aliran ini adalah Abu Sami al-Barudi, Ahmad Syaiqi Dayif, Abbas Mahmud al-'Aqqad di Mesir, Kazimi dan Rasafi di Irak, Muhammad Bazimi dan Khalil Bardum di Syiria, Basyarah al-Khuri sdan taimur alMalat di Libanon. Bagi kelompok ini, wazan atau irama puisi merupakan pondasi khas puisi Arab. Wazan adalah musik dalam seni, dan qafiyah sebagai nadanya. Hal ini pula yang seolah menjadi konsensus yang menyatakan bahwa wazan dan qafiyah merupakan karateristik puisi Arab yang mendarah daging dalam kesusastraan klasik dan modern. Seolah jika puisi Arab tidak berwazan dan berqafiah, maka puisi tersebut akan dianggap puisi yang asing.

Dalam ranah sastra prosa, aliran klasik berkiblat kepada gaya-gaya prosais klasik seperti Abdul Hamid, Ibn al-Muqaffa', dan al-Jahizh. Gaya prosa mereka berciri khas dengan fasahah (ketepatan diksi0 dan bayan (jelas makna). Gaya semacam ini memberikan sentuhan keindahan struktur bahasa dan makna yang tidak hanya mudah dicerna, tetapi juga memberikan rasa dan nada-nada khas yang dapat menyentuh hati dan pikiran. Diantara prosais modern yang beraliran ini adalah al-Manfaluthi dan al-Sadiq alRifa'i.

Aliran yang kedua adalah aliran romantisme (madrasah rumantikiyyah) ${ }^{21}$ yang mengedepankan emosi atau perasaan dalam ekpresi sastranya. Tujuan dari aliran ini adalah untuk menyentuh perasaaan para pembaca sehingga memunculkan gejolak dan konfilik dalam jiwanya. Ciri khas aliran ini adalah dengan menonjolkan keindahan alam yang natural atau kesedihan yang menguras emosi dan sentimen pembaca. Aliran ini terkenal dengansebutan aliran sentimentil karena mengedepankan rasa danjiwa daripada

${ }^{19}$ Sukron Kamil, Najib Mahfuz; Sastra, Islam dan Politik. Studi Semiotika terhadap Novel Aulad Haratina, (Jakarta: Dian Rakyat, 2013), hal. 2.

${ }^{20}$ Sukron Kamil, Teori Kritik Sastra Arab Klasik dan Modern, hal. 162-163.

${ }^{21}$ Sukron Kamil, Teori Kritik Sastra Arab Klasik dan Modern, hal. 165-167. 
rasio. Dalam kesusastraan Arab, di antara tokoh aliran romantisme adalah Umar bin Abi Rabi'ah, Jamil, Khalil Mutran, Abdurhahman Syukri, Abu Syadzi, Al-Mazini, Iliya Abu Madhi, dan Ibrahim Naji.

Aliran ini tidak berkutat pada bentuk puisi sebagaimana aliran klasik yang menekankan pentingnya wazan dan qafiyah. Bahkan aliran ini cenderung terpengaruh oleh struktur puisi Barat, khususnya Inggris dan Prancis. Meskipun pada era modern aliran ini lebih dipelopori para sastrawan Barat, namun pada praktiknya telah ada sejak praislam yang dipelopori oleh Umru al-Qais yang mengedepankan perasaan dan emosi kejiwaaan dalam puisi-puisinya. Dalam bidang prosa, novel Layla Majnun merupakan prosa yang sangat mengedepankan aspek romantisme. Pada masa modern, al-Manfaluti erkenal dengan gaya romantisme dalam kandungan makna karyanya meskipun dalam segi bentuk lebih cenderung klasik.

Ketiga adalah aliran realisme (madrasah waqi'iyyah) ${ }^{22}$ yang berusaha melukiskan suatu objek seperti apa adanya (realistis), tanpa mendramatisir dan memoles persitiwa. Para sastrawan yang menempuh aliran ini menjadikan kondisi masyarakat sebagai sumber dan pijakan dalam karyanya dengan teliti dan melebih-lebihkan. Sastrawan Arab yang termasuk dalam kategori ini adalah Yusuf Sibai, Taufiq Hakim, Mahmud Taimur, Taha Husein, dan Najib Mahfuzh yang memotret kehidupan masyarakat Mesir pada novel-novelnya.

Keempat, aliran simbolisme-filosofis (madrasah al-ramziyyah ${ }^{23}$ yang menggunakan simbol-simbol sebagai pijakan dalam karya sastranya. Kecenderungan aliran ini adalah penggunaan bahasa yang ambigu, multitafsir, dan sulit difahami tanpa pembacaan yang mendalam dan berulang-ulang. Sastrawan aliran ini biasanya menggunakan benda dan binatang sebagai tokoh-tokohnya. Dalam kesusatraan Arab, para sastrawan yang mengikuti aliran ini kebanyakan para penair sufi semisal Ibn Arabi, Umar Khayyam, Ibn Farid, Fariduddin al-Atthar. Dalam ranah prosa, Ibn al-Muqaffa' dengan Kalilah wa Dimnah, Ibnu Thufail dengan Hayy bin Yaqzan, Fariduddin al-Atthar dengan Mantiq al-Thayr, dan Najib Mahfuzd dalam dikategorikan sebagai sastrawan yang menempuh aliran ini.

Yang terkahir adalah aliran barnasiyah ${ }^{24}$ adalah aliran karya sastra yang sangat mementingkan bentuk dan struktur sastra. Aliranini tidak mempedulikan aspek moral, sosial, dan agama. Dalam sastra Arab, aliran ini mementingkan kaidah waazan, qafiah (Ilmu 'Arudh) dan gaya bahasa yang indah. Dalam kesusatraan Arab, Abu Nuwas merupakan tokoh yang termasuk dalam aliran ini. Ia menganut kebebasan dalam menuangkan rasa yang menurutnya indah tanpa menghirukan aspek moral dan etika kemasyarakatn di zamannya.

\section{b. Teori Kritik Sastra Strukturalisme ${ }^{25}$}

Teori kritik sastra strukturalisme merupakan bentuk kritik objektif yang menekankan aspek intrinsik karya sastra, teori ini lahir dari kaum formalis Rusia yang ingin membebaskan karya sastra dari lingkungan ilmu-ilmu lain, semisal psikologi, sejarah, atau penelitian kebudayaan. Dalam pandangan Levi-Strauss dan Roland Barthes, yang mengembangkan teori kritik sastra ini, kritik sastra harus berpusat pada karya sastra sendiri. Di Prancis aliran ini berkembang pesat di tangan Levi-Strauss dan Roland

\footnotetext{
${ }^{22}$ Sukron Kamil, Teori Kritik Sastra Arab Klasik dan Modern, hal. 168-167.

${ }^{23}$ Sukron Kamil, Teori Kritik Sastra Arab Klasik dan Modern, hal. 171-177.

${ }^{24}$ Sukron Kamil, Teori Kritik Sastra Arab Klasik dan Modern, hal. 178.

${ }^{25}$ Sukron Kamil, Teori Kritik Sastra Arab Klasik dan Modern, hal. 182-192.
} 
Barthes, di Inggris dipelopori oleh TS. Eliot. Begitu juga di Amerika ada aliran "New Criticism" yang dipelopori oleh WK. Wimsaat dan Jhon Crow Ransom.

Aliran formalis ini menekankan pada keindahan bahasa. Menurut aliran ini, karya sastra telah mengalami defamiliarisasi dan deotomatisasi. Relasi antara unsur dalam pandangan ini adalah karya sastra harus menjadi karya sastra yang otonom. Teori ini mempunyai tigas sifat, yaitu totalitas, perubahan bentuk, dan mengatur dirinya sendiri. Ketiga sifat diatas bisa disederhanakan dengan bahasa bahwa "dalam sebuah karya sastra seperti novel, pasti memiliki unusr-unsur intrinsik semisal plot, latar, tokok, dan gaya bahasa. Unsur-unsur tersebut harus bersifat totalitas (keseluruhan) dan berkaitan satu dengan yang lain. Dari unsur-unsur inilah sebuah karya bisa dikatakan tersruktur. Setiap sesuatu yang terstruktur bukan berarti harus statis, tetapi mengalami pergerakan kedinamisan. Inilah yang dinamakan dengan sifat perubahan bentuk atau transformasi. Dalam perubahan antar unusur disini yang memang dikemas menjadi satu struktur ini, maka antar unsur tersebut mengatur dirinya sendiri. Inilah yang dimaksud dengan dari tiga sifat di atas.

Dalam kesusatraan Arab, Muhammad Zaghlul Salam, Mahmud Zhihni, dan Susan Rajab, Ismail Mustafa termasuk dalam kelompok sastrawan strukturalisme karena mengakui keharusan unsur-unsur sastra yang menjadi satu kesatuan dan saling berkaitan dan mendukung, yaitu antara tokoh dengan karekternya (as-syakhshiyyah), plot atau alur (al-hakbah), setting (al-bi'ah), pikiran atau tema (alfikrah/al-maudhu'), dan gaya bahasa (uslub). Para stkruturalis kontemporen Arab yang paling konsern dalam hal ini diantaranya dalah Salah Fadal, Abdurahman Bu'ali, dan Gharib Iskandar.

\section{c. Teori Kritik Sastra Semiotik ${ }^{26}$}

Teori kritik sastra semiotik (simiyulujiyah/simiyaiyyah) adalah teori yang menekankan pada tanda. Istilah semiotik diperkenalkan oleh linguis Amerika, Charles Sanders Peirce. Semiotik merupakan istilah lain dari semiologi yang digunakan di negara-negara berbahasa Inggris sedangkan semiologi digunakan oleh negara-negara berbahasa Prancis. Secara umum, semiologi dan semiotik adalah ilmu yang mempelajari tentang tanda. Walaupun antara keduanya memiliki perbedaan yang tipis kedua istilah tersebut dipahami sebagai sinonim saja. Kemunculan ilmu tentang tanda sejatinya sudah diramalkan oleh linguis Swiss Ferdinad de Saussure dalam bukunya Corus de linguistique generale, dalam buku tersebut berpandangan bahwa bahasa merupakan sistem tanda yang mengekspresikan ide atau gagasan, dan tanda sendiri terdiri atas unsurunsur yang membentuk dan kaidah yang berlaku baginya.

Pierce mengemukakan bahwa tanda adalah sesuatu yang mewakili sesuatu. "Sesuatu" yang pertama merupakan aspek konkret atau yang dapat dicerna pancaindra, yang kemudian setelah melalui proses mewakili "sesuatu" kedua yang terdapat dalam kognisi manusia. Pendapat Pierce tentang tanda berbeda dengan teori Saussure yang bersifat dikotomis dan struktural karena mengaitkan dua segi saja, penanda (signifiant) dan petanda (signifie) atau bentuk dan makna, serta hubungan bentuk dan makna berdasarkan konvensi sosial belaka. Tanda dalam pandangan Pierce bukanlah struktur, melainkan proses kognitif yang berasal dari apa yang ditangkap oleh pancaindra.

Oleh karena itu, dalam teori semiotiknya Pierce mengemukakan tiga istilah yang membuat teorinya dikenal dengan sebutan semoitik trikotomis. Teori Pierce, "sesuatu" yang konkret yang bisa ditangkap pancaindra dinamakan dengan representamen, sedangkan "sesuatu" yang ada dalam kognisi atau sesuatu yang diwakili disebut obyek. Hal yang terakhir adalah interpretan, yaitu tanda yang hadir dalam pikiran si penerima

${ }^{26}$ Sukron Kamil, Teori Kritik Sastra Arab Klasik dan Modern, hal. 193-215 
setelah terjadinya proses hubungan dari representamen ke objek yang disebut semiosis. Proses pemaknaan tanda dalam pandangan Pierce tidak melulu harus dibatasi oleh kesepakatan sosial, melainkan proses semiosis tersebut terus berlanjut dan tidak terbatas. Jadi, interpretan dapat berubah menjadi representamen baru yang kemudian berproses mengikuti semiosis, secara tidak terbatas. Dalam proses itu, representamen berada di dalam kognisi, sedangkan kadar penafsiran makin lama menjadi makin tinggi.

Proses pemaknaan tanda versi Pierce melahirkan tiga jenis tanda, yaitu: ikon, indeks, dan simbol. Ikon adalah tanda yang didasarkan pada hubungan kemiripan atau tiruan, baik kemiripan bentuk seperti peta dan lukisan relais, atau kemiripan tahapan seperti pangkat militer dan tanda pangkat, maupun kemiripan sebagian seperti bunga mawar dan gadis. Indeks adalah tanda yang dibangun pada hubungan yang mempunyai jangkauan eksistensial atau keterkaitan, seperti tingkah laku manusia yang menunjukan indeks sifat-sifatnya, asap menunjukan indeks api, dan penunjuk jalan yang merupakan indeks arah sedangkan simbol atau lambang adalah tanda yang didasari atas konvensi masyarakat, seperti bahasa, rambu lalu lintas, dan sebagainya.

Proses pemaknaan tanda yang tidak terbatas dalam pandangan Pierce dapat dikatakan sebagai perluasan sekaligus juga pengembangan atas determinisme signifiant dan signifie Saussure karena semiotik model ini memberikan ruang bagi si penerima atau subjek untuk lebih bebas dan luas dalam memaknai tanda sesuai dengan ruang dan waktu yang dialaminya, tidak melulu harus sesuai atau paksaan konvensi masyarakat. Oleh karena itu, semiotik Pierce bisa dikatakan sangat dekat dengan jargon salah satu tokoh poststrukturalis Prancis, Jacques Derrida yang mengatakan bahwa il n'y a pas de horstexte, tidak ada apa-apa di luar teks atau yang ada hanyalah tanda. Maksudnya, teks atau tanda tidaklah menghadirkan suatu makna asli atau asumsi kebenaran murni yang menghadirkan sesuatu yang tidak hadir. Pendapat ini memberikan ruang penafsiran atas tanda atau teks dengan lebih bebas dan luas, tidak terikat dengan satu pakem yang menjadi kelumrahan dalam sebuah komunitas sosial.

\section{d. Teori Kritik Sastra Hermeneutika}

Secara terminologi, istilah hermenutika berasal dari bahasa Yunani. Sebagian peneliti memandang bahwa kata tersebut terbentuk dari verba "hermeneuein" dan nomina "hermeneia". Sebagian peneliti lain berpendapat bahwa hermeneutika berasal dari kata "hermeneutikikos". Ketiga akar kata tersebut memiliki arti yang sama, yaitu menjelaskan dan menghilangkan kesamaran. ${ }^{27}$ Konon, kata hermeneutika diasosiasikan dengan Hermes, mediator atau rasul dalam mitologi Yunani yang bertugas menyampaikan dan menjelaskan pesan-pesan para Dewa kepada manusia. ${ }^{28}$ Kedekatan kata Hermes dan hermeneutika -benar atau tidak- menyiratkan kemiripan pada aspek makna, yaitu seni memahami dan menafsirkan pesan tekstual. Hermenutika pada awalnya beroperasi dalam wilayah teologi yang bersentuhan dengan teks-teks keagamaan. Namun, pada abad ke-18 kajian hermeneutika merambah ke teks-teks nonkitab suci. ${ }^{29}$

Teks-teks historis tentu terasa asing dalam pandangan manusia sekarang. Secara historis teks tersebut sudah kuno dan asing bahasanya sehingga sulit dipahami oleh manusia yang tidak hidup pada masa bahasa teks tersebut digunakan. Sementara itu,

${ }^{27}$ Mu'tashim al-Sayyid Ahmad. Al-Hermenutiqa fi al-Wa $>q i$ ' al-Isla $>m i$, (Beirut: Da>r al-Ha>di, 2009), hal. 18.

${ }^{28}$ Beberapa intelektual muslim, seperti Sulaiman ibn Hasana ibn Jaljul Muhammad Tahir bin Asyur, dan Sayid Hossein Nasher, berpendapat bahwa Hermes adalah Nabi Idris as. Lihat:, M. Quraish Shihab, Kaidah Tafsir, (Tangerang: Lentera Hati: 2013), hal: 402.

${ }^{29}$ Adil Mustafa, Fahm al-Fahmi; Madkhal ila al-Hermenutiqa, (Kairo: Ru'yah, 2017), hal. 24. 
penafsir memiliki kecakapan yang memadai untuk berinterkasi dengan teks-teks tersebut, sehingga ia mampu menjadi mediator antara dua dunia, dunia teks asing dan dunia kekinian. Di sinilah Hermes dan hermenutika memiliki kesamaan fungsi dan peran, yaitu sebagai jembatan dalam menyampaikan dan mejelaskan pesan atau teks suci. ${ }^{30}$ Namun, keterkaitan dan kemiripan semacam ini diragukan oleh Hans Gadamer yang berpandangan bahwa hermenutika dan Hermes tak memiliki kaitan apapun. Gadamer beranggapan bahwa dalam perkembangannya, istilah hermeneutika yang terbentuk dari kata "hermeneias" atau "hermeneus" memiliki arti interpretasi ilmiyah atau penerjemahan. Sebab itu, hermenutika pada awalnya perkembangannya berarti tafsir. ${ }^{31}$

Hermeneutika adalah alat untuk menganalisis teks dan memahami maksudnya serta mengungkap kebermaknaan yang terkandung di dalamnya. Hermeneutika juga merupakan cara kerja yang wajib dilakukan oleh siapapun yang ingin memahami teks, baik yang terlihat nyata dari teksnya maupun samar bahkan tersembunyi akibat perjalanan sejarah atau pengaruh ideologi dan kepercayaan. ${ }^{32}$

Sementara itu, hermeneutika dalam arti luas adalah bidang ilmu yang membahas praktik penafsiran, metode-metode, prinsip-prinsip, dan filsafat penafsiran. ${ }^{33}$ Menurut Friedrich Schleiermacher hermeneutika adalah seni memahami bahasa orang lain secara benar, khususnya bahasa tulis. Menurut Gadamer, hermeneutika adalah seni menafsirkan dan juga sebagai disiplin yang membahas aspek metodis dan teoritis yang dapat menjustifikasi aktivitas penafsiran. Sedangkan menurut Franz-Peter Burkard, hermeneutika adalah seni menafsirkan teks dan refleksi teoritis tentang metode dan syarat pemahaman. $^{34}$

Ben Vedder memberikan penjelasan tentang keragaman dan lapisan definisi hermeneutika, yaitu: ${ }^{35}$

a. Hermeneuse yaitu penjelasan atau interpretasi sebuah teks, karya seni atau perilaku seseorang

b. Hermeneutik yaitu pembahasan tentang regulasi, aturan, metode, strategi, langkah penafsiran yang mengungkap kesatuan makna teks sesuai dengan kebenaran dan keobjektifan.

c. Philosophisce Hermeneutik adalah hemeneutika filosofis yang tidak lagi membicarakan metode eksegetik tertentu sebagai objek pembahasan inti, melainkan hal yang terkait dengan kondisi kemungkinan yang mana dengan hal itulah seseorang dapat memahami dan menafsirkan sebuah teks, simbol, atau perilaku.

d. Hermeneutische Philosophie (filsafat hermeneutis) adalah bagian dari pemikiran filsafat yang mencoba menjawab problem kehidupan manusia dengan cara menafsirkan apa yang diterima oleh manusia dari sejarah dan tradisi.

Nasr Hamid Abu Zaid berpendapat bahwa hermenutika merupakan sebuah istilah yang digunakan pada lingkup kajian teologi Kristen. Hermeneutika berarti kaidah-kaidah dan teori-teori yang wajib diikuti oleh penafsir dalam memahami Bibel. Dari aspek makna, hermenutika berbeda dengan istilah exegesis. Kata pertama mengandung makna

${ }^{30}$ Adil Mustafa, Fahm al-Fahmi, hal. 26

${ }^{31} \mathrm{Mu}$ 'tashim al-Sayyid Ahmad, Al-Hermenutiqa fi al-Wa $>q i$ ' al-Isla $>m i$, hal. 19.

${ }^{32}$ M. Quraish Shihab. Kaidah Tafsir, (Tangerang: Lentera hati, 2013), hlm. 401.

33 al-Mirzanah, Syafa'atun dan Sahiron Syamsuddin, ed. Upaya Integrasi Hermeneutika dalam Kajian Qur'an dan Hadis: Teori dan Aplikasi (Yogyakarta: Lembaga Penelitian UIN Suka, 2009), hlm. vii.

${ }^{34}$ Syafa'atun al-Mirzanah dan Sahiron Syamsuddin, ed. Upaya Integrasi Hermeneutika dalam Kajian Qur'an dan Hadis: Teori dan Aplikasi, hlm. 29.

${ }^{35}$ Syafa'atun al-Mirzanah dan Sahiron Syamsuddin, ed. Upaya Integrasi Hermeneutika dalam Kajian Qur'an dan Hadis: Teori dan Aplikasi hlm. 30-32. 
teori-teori penafsiran, sedangkan kata kedua bermuatan penafsiran praktis. Dalam perkembangannya, praktik teori hermeneutika yang sudah berlangsung sejak abad 17 ini tidak saja diterapkan pada lingkup teks-teks suci, tetapi juga pada lingkup humaniora, seperti sejarah, sosiologi, antropologi, filsafat estetika, kritik sastra, dan folklor. ${ }^{36}$

Menurut Nasr Hamid, fokus hermeneutika adalah hubungan interaksi penafsir dengan teks. Kecenderungan hermeneutika seperti ini tidak hanya terdapat pada budaya non-Islam, namun juga sudah diterapkan dalam tradisi umat Islam. Dalam tradisi Islam dikenal tafsi $>r$ bil matsu $>r$ dan tafsi $>r$ bil $r a y^{\prime} y$ atau ta wil. Tafsir yang pertama merupakan model penafsiran yang berlandaskan pada argumen dan landasan historis dan linguistik dalam mengungkap makna sebuah teks, sehingga karakter tafsirnya menjadi objektif sebagaimana yang dipahami oleh manusia yang hidup saat teks turun. Adapun tafsir model kedua dikategorikan sebagai tafsir non-objektif lantaran penafsir tidak berpijak pada realitas historis dan bahasa, tetapi berpedoman pada konteks si penafsir dalam menyingkap kebermaknaan teksnya. ${ }^{37}$

Secara ringkas, hermeneutika adalah teori-teori yang diterapkan dalam menganalisis dan memahami maksud kebermaknaan teks serta menggali nilai-nilai yang terkandung di dalamnya. Hermeneutik identik dengan penafsiran teks-teks lama yang telah melewati beberapa masa yang panjang. Biasanya teks-teks teresbut berkaitan dengan lingkup sejarah dan keagamaan. ${ }^{38}$ Menurut para pakar Arab dalam bidang penafsiran, hermenutika sering dipadankan dengan istilah 'Ilm at-Ta'wi>l atau atTawiliyah. Bahkan ada ulama yang menyamakannya dengan Ilmu Tafsir dengan alasan bahwa fungsi keduanya memang menerangkan dan menganalisis maksud sebuah teks yang dikaji. Bagi Quraish Shihab, padanan kata hermeneutik yang mendekati adalah ' $\mathrm{Im}$ at-Ta'wi $>l$ atau at-Tawiliyah karena fokus utama dalam analisisnya adalah penafsiran teks dari satu makna ke makna yang lebih tepat dalam pandangan penakwil. ${ }^{39}$

Hermenutika sebagai sebuah kaidah dan teori berkutat pada tiga poros utama, yaitu pencipta atau pengarang atau penulis, teks, dan pembaca atau penafsir atau peneliti. Ketiga unsur ini berkelindan dalam proses penafsiran sebuah teks. Namun, para pelopor hermeneutika memiliki kecenderung masing-masing dalam melihat sudut mana dari ketiga unsur itu yang lebih berperan sehingga maksud teks dapat dianalisis dengan benar atau mendekati kebenaran. Kecenderungan tentu memberikan implikasi pada corak dan model hermeneutik dalam perkembangannya. Hermeneutik mengalami perkembangan dan perubahan karakter dari masa ke masa sesuai dengan kondisi epistemologi ilmu pengetahuan yang melingkupinya. Secara garis besar ada dua mazhab utama dalam hermeneutika yang pengaruh pemikirannya masih terasakan sampai saat ini.

Pertama, mazhab klasik romansis ${ }^{40}$ yang diprakarsai oleh Friedrich Schleiermacher (1768-1834 M) dan Wilhelm Diltheiy (1833-1911 M). Mazhab ini merupakan pondasi awal hermeneutika. Model hermeneutika awal ini dikenal dengan hermeneutika objektif, yang menekankan pada penafsiran teks yang selaras dengan maksud si pengarangnya. Hal ini didasarkan karena sebuah teks merupakan representasi dari kesadaran jiwa pengarangnya. Karena itu, penafsiran teks bukan didasarkan pada asumsi-asumi dan kesimpulan si penafsir sendiri, melainkan berpijak pada apa yang dihadirkan si pengarang melalui aspek kebahasaannya. Menurut mazhab ini, ada dua hal yang harus diperhatikan dalam meneliti sebuah teks, yaitu teks dan pengarang teks. Yang

\footnotetext{
${ }^{36}$ Nashir Hamid Abu Zaid, Isyka >liyat al-Qira>ah wa A>liyat al-Tawil, hal. 13

${ }^{37}$ Nashir Hamid Abu Zaid, Isyka >liyat al-Qira >ah wa A >liyat al-Tawil, hal. 15

${ }^{38}$ M. Quraish Shihab, Kaidah Tafsir, hal: 401

${ }^{39}$ M. Quraish Shihab, Kaidah Tafsir, hal: 402

${ }^{40}$ Shihab, M. Quraish. Kaidah Tafsir, hal: 408-415.
} 
pertama berkaitan erat dengan aspek kebahasaan teks yang menjadi penghubung interaksi antara pengarang dan penafsir. Aspek kedua berhubungan dengan tujuan dan maksud pengarang saat menciptakan karyanya.

Mazhab ini menekankan pada usaha penafsir agar dapat menggali maksud pengarang yang tersembunyi dan terkandung pada sebuah teks. Untuk mencapai hal tersebut penafsir harus mengetahui konteks sebuah teks yang akan dikaji, baik yang berkaitan dengan kondisi sosial budaya di masa pengarang maupun pengalaman dan pandangan kehidupan pengarang sendiri. Bagi mazhab ini, penafsir teks harus hidup di masa pengarang agar mampu memahami dengan benar maksud dan tujuan pengarang dalam teks yang dikajinya. Pemahaman mazhab ini mengantarkan pada asumsi bahwa teks memiliki makna objektif dan absolut. Kecenderungan ini merupakan ciri khas yang dimiliki oleh mazhab klasik, meskipun ada yang menekankan pada psikologis pengarang dan ada pula yang lebih mengedepankan konteks sosio kultural yang melatarbelakangi lahirnya sebuah karya tekstual.

Kedua, mazhab yang cenderung melihat pada aspek penafsir atau yang dikenal dengan hermeneutika subjektif. ${ }^{41}$ Model ini merupakan anti klimaks dari yang pertama. Fokus hermeneutika subjektif bukan untuk menemukan makna objektif pengarang seperti yang diasumsikan mazhab pertama melainkan memahami teks secara mandiri, terlepas dari latar belakang dan pengaruh pengarangnya. Sebuah teks bersifat otonom, kebermaknaannya tidak tergantung pada pengarangnya. Kecenderungan ini merupakan ciri khas mazhab subjektif yang dikenal juga dengan hermeneutika filosofis. Pelopor mazhab ini adalah Martin Heideggar (1889-1976 M). Heideggar melihat bahwa sebuah karya memiliki wujud sendiri, sebab itu tidak penting mengetahui dan memahami tujuan pengarang. Yang terpenting dalam interkasi dengan teks adalah pembacaan dan pemahaman penafsir sesuai dengan pengetahuan dan konteks sosial budayanya. Heideggar berpendapat bahwa penafsiran tidak bersifat tunggal, tetapi sangat beragam sejalan dengan perbedaan latar belakang penafsirnya. Bagi mazhab ini, proses penafsiran adalah proses dialog sebuah karya dengan penafsir yang memiliki pengetahuan, pemikiran, dan pemahaman yang telah ada sebelum berinteraksi dengan karya yang dikaji. Atas dasar ini, sebuah penafsiran merupakan proses penyingkapan makna-makna baru berdasar pengalaman penafsirnya.

Mazhab ini dikembangkan juga oleh Hans Georg Gadamer (1900-2002 M). Ia berpadangan bahwa mazhab klasik tidak mampu melampuai batas-batas metode sehingga menghasilaknan apa yang dibahas saja. Baginya, hermeneutika objektif tidak mampu membantu dalam memahami sebuah teks karena ada jurang yang memisahkan penafsir dan teks. Juga mustahil penafsir nir pengetahuan dan pengalaman saat berinteraksi dengan sebuah teks. Pengalaman dan pengetahaun ini yang kemudian berpengaruh dalam mereproduksi penafsiran dan pemaham baru, bukan mereproduksi makna awal. Ada empat pijakan dalam hermenutika subjektif yang kembangkan oleh Gadamer, yaitu: otonomi teks yang terlepas dari pengarang, penyingkapan makna baru versi penafsir pada teks, makna teks tidak tunggal dan tidak ada penafsiran atau pemaknaan objektif, dan penafsir memiliki kebebasan dalam menyelami teks, tidak terkungkung oleh metode dan teori tertentu.

Dalam hal ini, dari kritikus Sastra Arab yang paling populer adalah Abdul alQahir al-Jurjani. Yang dikenal sebagai pakar penolakan atas ucapan yang mengatakan bahwa "dalam suatu karya sastra, yang bertambah adalah maknanya bukanlah lafadnya",

${ }^{41}$ Shihab, M. Quraish. Kaidah Tafsir, hal: 416-426, 
berbeda dengan pendapatnya beliau yang menagtakan "bukanlah makna yang bertambah, melainkan lafalnya. Keindahan utama bahasa, terletak pada makna yang dikandungnya".

\section{e. Teori Kritik Sastra Sosiologi}

Sosiologi dan sastra membicarakan objek yang sama, yaitu manusia dan masyarakat. Jadi, pendekatan terhadap sastra yang mempertimbangkan segi-segi kemasyarakatan itu disebut sosiologi sastra dengan menggunakan analisis teks untuk mengetahui strukturnya, untuk kemudian dipergunakan memahami lebih dalam lagi gejala sosial yang di luar sastra. Hal ini dapat dipahami karena sosiologi sastra terilhami dari konsep mimetik yang diungkapkan Plato, bahwa karya sastra merupakan tiruan dari keyataan. Murid Plato, Aristoteles menambahkan bahwa dalam meniru realitas sastrawan juga menciptakan hal baru. ${ }^{42}$ Menurut Sapardi Djoko Damono, karya sastra dapat dilihat dari kacamata sosiologi dengan mempertimbangkan aspek kemasyarakatan, relasi manusia dengan lingkungannya, struktur masyarakat, lembaga, dan proses sosial. Diungkapkan lebih lanjut bahwa di dalam ilmu sastra apabila sastra dikaitkan dengan struktur sosial, hubungan kekeluargaan, pertentangan kelas, dan lain-lain dapat digunakan sosiologi sastra. ${ }^{43}$

Sosiologi sastra merupakan keniscayaan berdasarkan beberapa alasan, diantaranya adalah dikarenakan pengarang merupakan salah satu anggota masyarakat, maka tak mengherankan kalau terjadi interelasi antara pengarang dan masyarakatnya dan tentu selalu dapat ditarik sifat hubungan antara sastra dengan masyarakat tempat pengarang hidup. Oleh sebab itu, suatu karya sastra sering kali dianggap sebagai ekspresi pengarang. Bentuk ini kemudian dilihat dari suatu paradigma bahwa struktur sosial pengarang dapat mempengaruhi penciptaan bentuk karya sastra tersebut. Sebab itu, sifat dan persoalan suatu zaman dapat dibaca dalam karya-karya sastranya. Begitu pula harapan-harapan, penderitaan-penderitaan, aspirasi-aspirasi masyarakat menjadi bagian pribadi pengarang-pengarangnya. ${ }^{44}$

Ada dua arus utama dalam telaah sosiologi sastra. Pertama, pendekatan yang berdasarkan pada anggapan bahwa sastra merupakan cermin proses sosial ekonomi belaka. Kedua, pendekatan yang mengutamakan teks sastra sebagai bahan penelaahan yang kemudian dicari aspek-aspek sosial dari karya sastra. ${ }^{45}$ Pemahaman sosilogis dalam sastra merupakan cara lain dalam mengimplikasikan teori sastra yang makin berkembang dengan cara mempelajari sifat hubungan antaranggota masyarakat sastra dan mengetahui sebab-sebab terciptanya hubungan itu dengan segala akibatnya. ${ }^{46}$

Pendekatan sosiologi sastra memiliki tiga sasaran. Pertama, konteks sosial pengarang yang memiliki hubungan sosial dalam masyarakat dan kaitannya dengan masyarakat pembaca. Dalam hal ini termasuk juga faktor-faktor sosial yang dapat mempengaruhi karya sastranya. Oleh karena itu, yang diteliti dalam hal ini kehidupan pribadi pengarang atau sastrawan, sikap profesinalisme sastrawan terhadap profesinya, dan masyarakat yang dituju oleh sastrawan dalam karya sastranya. ${ }^{47}$

\footnotetext{
${ }^{42}$ Sukron Kamil, Teori Kritik Sastra Arab Klasik dan Modern, hal. 113

${ }^{43}$ Sapardi Djoko Damono, Sosiologi Sastra, (Semarang: Magister Ilmu Susastra Undip, 2003), hal. 210.

${ }^{44}$ Wahyuningtyas dan Santoso, Sosiologi Sastra: Teori dan Implementasi, hal. 25

${ }^{45}$ Wahyuningtyas dan Santoso, Sosiologi Sastra: Teori dan Implementasi, (Surakarta: Yuma Pustaka, 2011), hal. 20.

${ }^{46}$ Wahyuningtyas dan Santoso, Sosiologi Sastra: Teori dan Implementasi, hal. 24

${ }^{47}$ Sapardi Djoko Damono, Sosiologi Sastra; Sebuah Pengantar Ringkas (Jakarta: Pusat Pembinaan dan Pengembangan Bahasa, 1979), hal. 3.
} 
Kedua, sastra sebagai cerminan kondisi dan keadaan masyarakatnya. Kata "cermin" di sini dapat menimbulkan gambaran yang kabur. Karena itu sering disalahartikan dan disalahfahami. Dalam sasaran ini, harus diperhatikan bahwa sastra dapat dikatakan mencerminkan masyarakat pada waktu ia ditulis, sebab banyak ciri masyarakat yang ditampilkan dalam karya sastra itu sudah tidak berlaku lagi pada waktu ia sudah ditulis. Sastrawan juga memiliki andil besar dalam menampilkan fakta-fakta sosial dalam karyanya. Corak sastra merupakan sikap sosial suatu kelompok tertentu, bukan sikap sosial seluruh masyarakat. Karena itu, karya sastra yang berusaha menampilkan keadaan masyarakat dengan secermat-cermatnya bisa saja tidak dapat dipercaya sebagai cermin masyarakat. Pun sebaliknya, karya sastra yang sama sekali tidak dimaksudkan untuk menggambarkan keadaan masyarakat secara teliti mungkin bisa diterima sebagai bahan untuk mengetahui keadaan masyarakat. Pandangan sosial sastrawan mutlak harus diperhatikan apabila sastra akan dinilai sebagai cermin masyarakat. ${ }^{48}$

Ketiga, pendekatan sosiologi sastra melihat karya sastra sebagai "nilai" sosial yang terkonsep oleh sastrawan, sehingga nilai sastra dan nilai sosial menjadi saling berkaitan dan mempengaruhi satu sama lain. Oleh karena itu, ada sudut padang yang menganggap bahwa sastra sama derajatnya dengan karya pendeta atau nabi. Dalam pandangan ini, tercakup juga pandangan bahwa sastra harus berfungsi sebagai pembaharu dan perombak. Sudut pandang lain menganggap bahwa sastra bertugas sebagai penghibur belaka. Dalam hal ini gagasan-gagasan seni untuk seni misalnya, tidak ada bedanya dengan usaha untuk melariskan dagangan agar menjadi laku. terdapat juga sudut pandang kompromistis seperti tergambar sastra harus mengajarkan dengan cara menghibur. ${ }^{49}$

Dalam sastra Arab, sosiologi sastra sudah sejak lama diterapkan meskipun tidak terkonsep secara detail sebagai sebuah kritik sastra. Puisi-puisi pra-Islam dan magnum opusnya "al-mu'allaqat" merupakan cermin kebahasaan dan sosial pada zamannya. Lebih khusus lagi pada masa-masa setelahnya, seperti al-Bukhala dan 'Uqala al-Majanin karya Jahizh yang memotret kondisi kemasyarakatan pada satu masa di zaman Abasiyah. Pada mas modern, kecenderungan ini juga menjadi perhatian para sastrawan Arab, khususnya Syibli Syamil, Salamah Musa, Umar Fakhuri, Muhammad Amin al-Alim, Abdul Azhim Anis, dan Louis 'Awad. ${ }^{50}$

\section{KESIMPULAN}

Kritik sastra memberikan inspirasi terhadap fungsi kritik sastra itu sendiri. Dengan demikian bentuk fungsi kritik sastra adalah interpretasi, penilaian, dan sekaligus kontrol terhadap sastra tersebut. Sisi kritik intrinsikalitas dan ekstrensikalitas memberikan peluang hidupnya makna dan nilai kehidupan melalui karya-karya sastra. Melalui kritik inilah kemultidisiplineran terhadap sastra melalui kajian-kajian yang mengaitkan dengan disiplin-disiplin ilmu lainnya, sehingga terjadi interaksi konstruktif antara karya, pembaca, dan realita yang melingkupinya.

\footnotetext{
${ }^{48}$ Sapardi Djoko Damono, Sosiologi Sastra; Sebuah Pengantar Ringkas, hal. 3.

${ }^{49}$ Sapardi Djoko Damono, Sosiologi Sastra; Sebuah Pengantar Ringkas, hal. 4.

50 Azadah Muntazhori, “al-Naqd al-Ijtima' lil Adab, Nasyatuhu wa Tathowuruhu”, Jurnal Idha 'at Naqdiyah, Vol. 6, Juni (Haziran) tahun 2012.
} 


\section{DAFTAR PUSTAKA}

Nashir, Batul Qasim. Muhadharat fi al-Naqd al-Arabi. Baghdad: Markaz al-Syahidain alShadrain, 2008.

Kamil, Sukron. Teori Kritik Sastra Arab Klasik dan Modern. Jakarta: RajaGrapindo Persada, 2012.

Amin, Ahmad. al-Naqd al-Adabi. Kairo: Kalimat Arabia, 2012.

Abbas, Ihsan. Tarikh al-Naqd al-Adab 'Inda al- 'Arab. Beirut: Daar Al-Tsaqafah, 1983.

Pradopo, Rachmat Djoko Prinsip-Prinsip Karya Sastra. Yogyakarta: Gadjah Mada University Press, 2007.

Suhariyadi. Pengantar Ilmu Sastra; Orientasi Penelitian Sastra. Lamongan: Pustaka Ilalang, 2014.

Sayuti, Suminto A. "Kritik Sastra: Sebuah Tinjauan Umum”, Jurnal Diksi, No. 1 Tahun 1, Januari 1993.

Kamil, Sukron. Najib Mahfuz; Sastra, Islam dan Politik. Studi Semiotika terhadap Novel Aulad Haratina. Jakarta: Dian Rakyat, 2013.

Ahmad, Mu'tashim al-Sayyid. Al-Hermenutiqa fi al-Wa $>$ qi' al-Isla $>m i$. Beirut: Da>r alHa>di, 2009.

Shihab, M. Quraish. Kaidah Tafsir. Tangerang: Lentera Hati: 2013.

Mustafa, Adil. Fahm al-Fahmi; Madkhal ila al-Hermenutiqa. Kairo: Ru'yah, 2017.

al-Mirzanah, Syafa'atun dan Sahiron Syamsuddin, ed. Upaya Integrasi Hermeneutika dalam Kajian Qur'an dan Hadis: Teori dan Aplikasi.Yogyakarta: Lembaga Penelitian UIN Suka, 2009.

Abu Zaid, Nashr Hamid, Isyka >liyat al-Qira>ah wa A>liyat al-Tawil, Beirut: al-Markaz al-Tsaqafi al-'Arabi, 2005.

Damono,Sapardi Djoko. Sosiologi Sastra. Semarang: Magister Ilmu Susastra Undip, 2003.

Wahyuningtyas dan Santoso. Sosiologi Sastra: Teori dan Implementasi. Surakarta: Yuma Pustaka, 2011.

Damono, Sapardi Djoko. Sosiologi Sastra; Sebuah Pengantar Ringkas. Jakarta: Pusat Pembinaan dan Pengembangan Bahasa, 1979.

Muntazhori, Azadah. "al-Naqd al-Ijtima' lil Adab, Nasyatuhu wa Tathowuruhu”, Jurnal

Idha`at Naqdiyah, Vol. 6, Juni (Haziran) tahun 2012. 